\title{
BIOSTRATIGRAPHIC STUDY OF THE GURPI FORMATION BASED ON PLANKTONIC FORAMINIFERA IN Lar area (Kuh - e -kurdeh section)
}

\author{
Shafiee Ardestani $\mathrm{M}^{1^{*}}$ Ghasemi- Nejad E Mandanizadeh $\mathrm{A}^{2}$ \\ 1- Department of Geology, Faculty of Science,University of Tehran,Tehran,Iran \\ 2- Iranian Central Oil Fields Company (I.C.O.F.C) \\ *Corresponding author: m_shafiee@khayam.ut.ac.ir( Shafiee Ardestani M)
}

\begin{abstract}
The study of planktonic foraminifera of the Gurpi formations at Lar area (Kuhe-kurdeh section) enables me to find the most standard biozones defined in mediterranean regions, especially Tethysian domain. Five biozones were determined. Biozones I (Globotruncanita elevata zone) and II (Globotruncana ventricosa zone) and III (Radotruncana calcarata zone) indicate the Early Campanian and Middle and Late Campanian, respectively. Biozones IV (Globotruncanita stuarti zone) and V (Gansserina gansseri zone) suggest the Early and Middle Maastrichtian, respectively. In the Late Maastrichtian, due to decreasing in water depth at the study area, Abathomphalus mayaroensis zone defined in Tethysian domain was not recognised.
\end{abstract}

Keywords: Gurpi Formation; Upper Cretaceous; Planktonic Foraminifera; Biozonation 


\section{Introduction}

At the type section (E: $\left.49^{\circ} 13^{\prime} 47^{\prime \prime}, \mathrm{N}: 32^{\circ} 26^{\prime} 50^{\prime \prime}\right)$, the Gurpi Formation composed of 320 meters grey to blue marl and shale beds and occasionally thin beds of argillaceous limestone (Darvishzadeh,1992, James \& Wynd,1965, Motiei, 1993, Setudehnia,1972). The Gurpi Formation overlies the Ilam Formation and is disconformably overlain by the Pabdeh Formation at the type section (Motiei, 1993). The main purpose of this research was to identify a biostratigraphic zonation of Gurpi Formation in Lar area (Kuh-e-kurdeh section) and correlation with Gurpi type section in Lali area and other Micro fauna of Gurpi Formation were studied by universally accepted biozones. Kalantary

and

Jalali

(1971).

\section{Study Area and Methodology}

The study area is located in $12.5 \mathrm{Km}$ of NE of Lar, South of Iran (E: $54^{\circ} 36^{\prime}$ 35", $\quad$ N: $27^{\circ} 44^{\prime} 08^{\prime \prime}$ ) (Fig.1). Fieldwork was concentrated at the Kuh-ekurdeh.

The thickness of Gurpi Formation is 70 meters in studied section and consists of: Marl, Limy marl, Marly shale and Marly limestone. It unconformably overlies the Ilam Formation and is overlain by the Tarbur Formation.

Samples were taken almost every 2 meters. Approximately 90 samples were collected. Samples were studied by two ways: Hard samples were studied by making thin sections and soft samples were studied by washing method. Dried residues were then size sorted through sieves at half -phi intervals from $500 \mu \mathrm{m}$ 
down to $63 \mu \mathrm{m}$. Foraminifera were picked and studied from the residues in the 250-355 $\mu \mathrm{m}$ size fractions.

After particular process had been carried out, Foraminifera were studied in thin section and Scanning Electronic Microscope (S.E.M).

Foraminifer's taxonomy and nomenclature follows Bolli and et. (1987), Leoblich and Tappan (1964, 1987), Sliter (1989) ,Longoria (1991), Robaszynski and Caron,1979,1995 ,Premoli Silva and Sliter 1995, Loeblich and Tappan 1998, Ellis and Messina 1999, Premolisilva and Verga,2004).

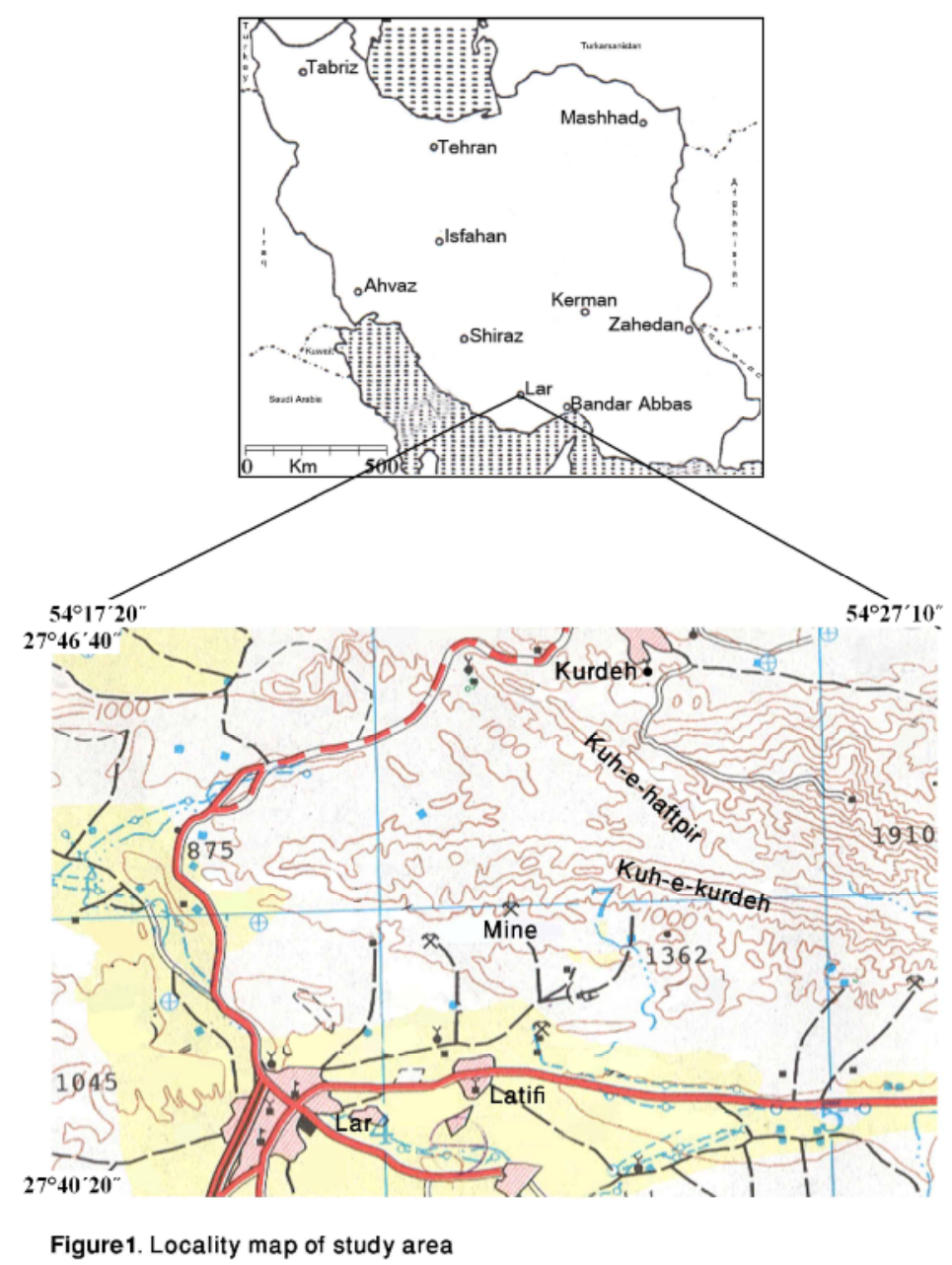




\section{Results and Discussion}

Biostratigraphy

Planktonic foraminifera are important to universal biostratigraphy zonation of Upper Cretaceous marine sediments. The value of these foraminifera for correlation has been discussed by Bandy (1967).

10 genera and 22 species of planktonic foraminifera were recognized at the studied area, also 5 biozones were identified in thin section and isolated specimens (Fig.2).

\section{1- Globotruncanita elevata biozone:}

Author: Dalbiez (1955)

Definition: Partial range zone from the first appearance of Globotruncanita elevate to the first appearance of Globotruncana ventricosa.

Characteristics: The first occurrence of the genus Globotruncana arca, Globotruncana bulloides, Globotruncana lapparenti and Rosita fornicata has been taken in this biozone.

Age: Early Campanian.

This biozone was recorded from Tethys (Caron, 1978, Sliter, 1989) and Sarvestan area (Vaziri Moghaddam, 2002) from the Early Campanian.

\section{2- Globotruncana ventricosa biozone:}

Author: Dalbiez (1955)

Definition: Interval zone from the first appearance of Globotruncana ventricosa to the first appearance of Globotruncanita calcarata. 
Characteristics: Globotruncana arca, Globotruncana bulloides, Globotruncana lapparenti, Rosita fornicata and Globotruncana linneiana are observed in this biozone.

Remarks: The last occurrence of Rosita patelliformis is in this biozone.

Age: Middle Campanian.

This biozone was recorded from Tethys (Caron, 1978, Sliter, 1989) and Sarvestan area (Vaziri Moghaddam, 2002) from the Middle Campanian.

\section{3- Radotruncana calcarata biozone:}

Author: Herm (1962)

Definition: Total range zone of Globotruncanita calcarata.

Characteristic: The dominant taxa in this biozone are: Globotruncana arca, Globotruncana bulloides, Globotruncana lapparenti, Globotruncana linneiana and Contusotruncana fornicata.

Remarks: The first occurrence of Globotruncanita stuarti is in this biozone. Age: Late Campanian.

This biozone was recorded from Central Tethys (Barr, 1972), Tethys (Caron, 1978, Sliter, 1989) and Sarvestan area (Vaziri Moghaddam, 2002) from the Late Campanian. 
Author: de Lapparent (1918)

Definition: Partial range zone from the last appearance of Globotruncanita calcarata and the first appearance of Gansserina gansseri.

Characteristics: Globotruncana arca, Globotruncana bulloides, Globotruncana lapparenti and Globotruncanita stuartiformis are occurred in this biozone.

Remarks: The first occurrence of Globotruncanita stuartiformis and Globotruncana falsostuarti is in this biozone.

Age: Early Maastrichtian.

This biozone was recorded from Central Tethys (Barr, 1972), Zagros (Wynd, 1965) and Sarvestan area (Vaziri Moghaddam, 2002) from the Lower Maastrichtian.

\section{5- Gansserina gansseri biozone:}

Author: Bronnimann (1952)

Definition: Interval zone from the first appearance of Gansserina gansseri to Gurpi-Tarbur Formations boundary (Abathomphalus mayaroensis biozone was not found in this section).

Characteristics: The dominant taxa in this biozone are: Globotruncana linneiana, Globotruncana falsostuarti, Globotruncanita stuarti and Globotruncanita stuartiformis.

Remarks: The first occurrence of Contusotruncana contusa is recorded in this biozone.

Age: Middle-Upper Maastrichtian.

This biozone was recorded from Central Tethys (Barr, 1972), Tethys (Caron, 1978, Sliter, 1989) and Sarvestan area (Vaziri Moghaddam, 2002) from the Middle-Upper Maastrichtian. 
Table 1 also shows the correlation of the proposed biostratigraphic zonation in this study with some zonal schemes from other localities. The proposed scheme most closely resemble to Vaziri Moghaddam(2002) for Sarvestan area (SE of Shiraz, Iran).

Globotruncanella havanensis and Globotruncana aegyptica are rared in this area; therefore these species can not form any biozones too. In the Late Maastrichtian, water depth decreased and limestones of the Tarbur Formation overlies the Gurpi Formation, therefore the Abathomphalus mayaroensis biozone was not recognized at this section. 


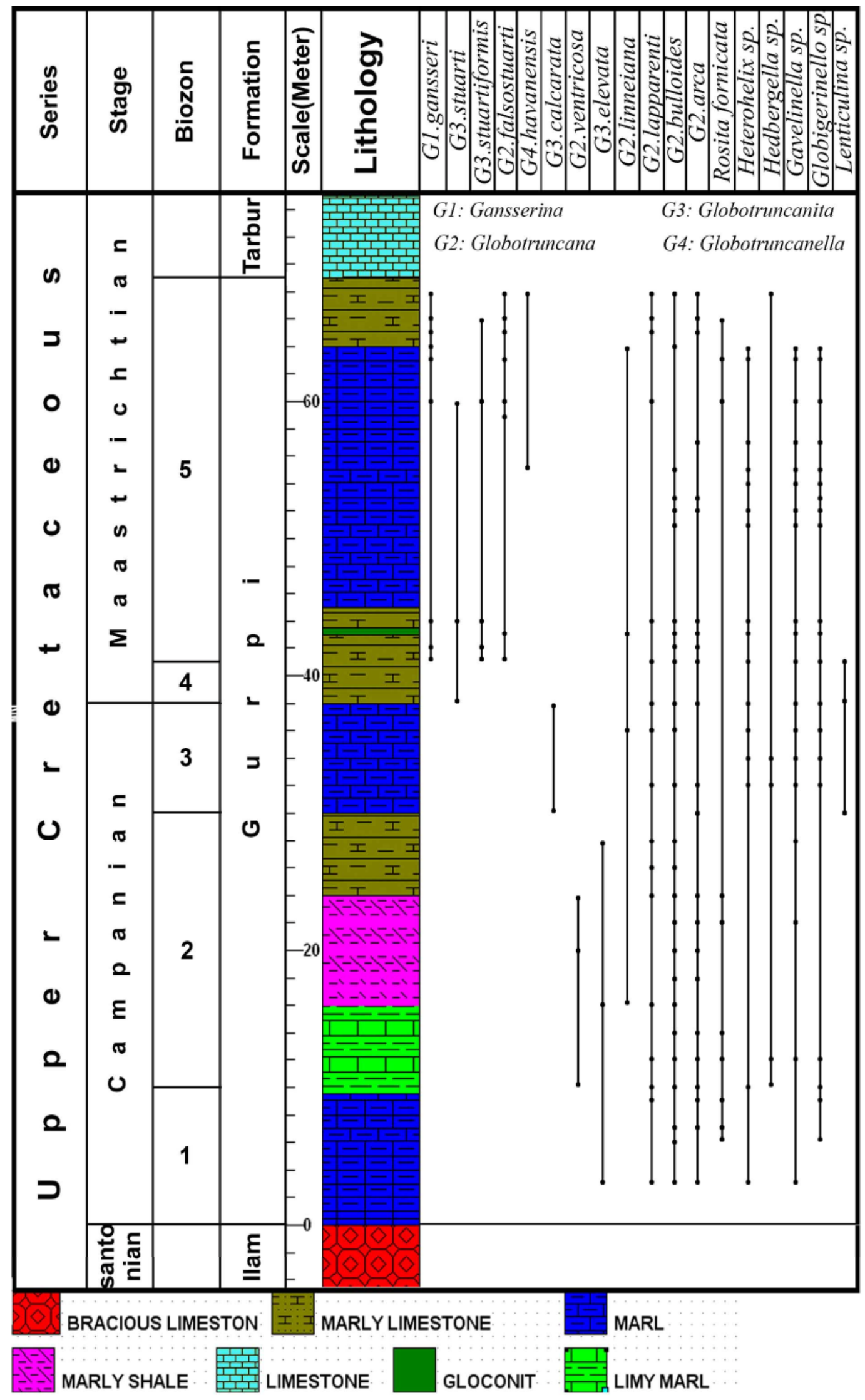

Figure2. Distribution and planktonic foraminiferal zonation of the Gurpi Formation at Lar area 


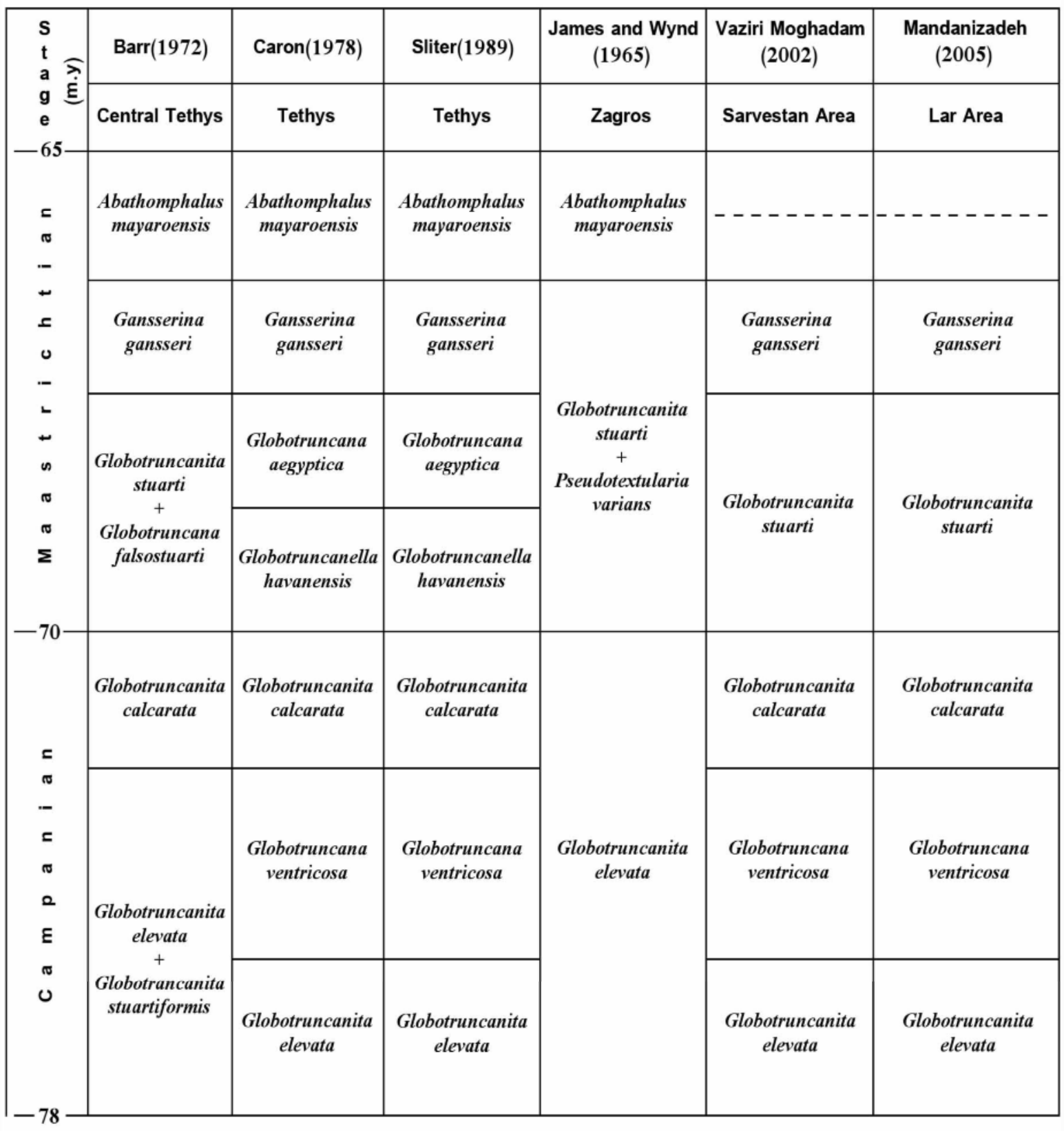

Table1. Correlation of the proposed biostratigraphic zonal scheme at Lar area with other accepted standard biozones of other parts of the world 


\section{Conclusion}

a) 10 genera and 22 species of planktonic foraminifera were identified from Gurpi Formation in Lar area (Kuh-e-kurdeh section).

b) 5 biozones were identified, respectively: Globotruncanita elevata (Early Campanian), Globotruncana ventricosa (Middle Campanian), Radotruncana calcarata (Late Campanian), Globotruncanita stuarti (Early Maastrichtian) and Gansserina gansseri (Middle-Upper Maastrichtian).

c) The proposed zonal scheme is most closely resemble to Vaziri Moghaddam (2002), Sliter

d) Due to decreasing of water depth in the upper Maastrichtian, Abathomphalus mayaroensis biozone was not recognized at the studied area.

e) Observing of Abathomphalus intermedius shows that age of Gurpi Formation in Lar area is Early Campanian-Late Maastrichtian. 


\section{References}

Bandy, O.L, 1967, Cretaceous planktonic foraminiferal zonation.Ibid. 13: 1-13

Barr, F.T, 1972, Cretaceous biostratigraphy and planktonic foraminifera of Libya. Micropaleontology, 18, 1-46

Bolli, M, J.B, Saunders, and K.P. Nielsen, 1987, Plankton Stratigraphy: Cambridge University Press, 1023 p.

Bronnimann, P, 1952, Globigerinidae from the upper Cretaceous (CenomanianMaastrichtian) of Trinidad, B.W.I, Bull, Am, paleontol, 34: 5-71

Caron, M , 1978 , Cretaceous planktonic foraminifers from DSDP Leg 40, Southeastern Atlantic Ocean, initial Rep. Deep Sea Drill Proj.,40:651-78

Dalbiez, F, 1955, The genus Globotruncana in the Tunesia, Micropaleontology, 1:161-71

Darvishzadeh, A, 1992, Geology of Iran: Tehran, Amirkabir, Publication Company, 625 pp, In Farsi

Ellis,B.F.Messina,A.R. 1999. Catalogue of foraminifera on CD ROM.American Museum of Natural History

Herm, D, 1962, Stratigraphische und mikropalaontologische unterschungen der oberkriede im Lattengebrige und im Nierental.Abh.Bayer.Akad.Wiss, Munchen, new ser., 104: 1-119

Premoli Silva, I, Verga, D, 2004, Practical manual of cretaceous planktonic foraminifera

Jalali, M.R, 1971, Stratigraphy of Zagros basin: National Iranian Oil Company, Exploration and Production Division, Report nos.1249 and 1072: 34-36, Unpublished, In Farsi

James, G.A, and Wynd, J.C, 1965, Stratigraphy Nomenclature of Iranian Oil Consortium Agreement Area: American Association Petroleum Geologist Bulletin, 49

Kalantary, A , 1992, lithostratigraphy and Microfacies of Zagros Orogenic Area, S.W. Iran, National Iranian Oil Company, Exploration and Production, Geological Laboratories, Pub. No. 12: 421, In Farsi

Lapparent, J.de, 1918, Etude lithologique des terrains crétacés de la région d' Hendaye. Mémoire pour server á l’ explication de la carte géologique de la France. 115 pp

Leoblich, A.R.Jr and Tappan, H, 1964, Foraminifera classification and evolution, J.geol.Soc.India, 5: 6-40

Leoblich, A.R.Jr and Tappan, H, 1987, Foraminiferal genera and their classification, Van Nostrand Reinhold Company, New York. 2 volumes

Longoria, J.F, and VonFeldt E., 1991, Taxonomy, phylogenetics and biochronology of single-keeled globotruncanids (Genus Globotruncanita Reiss), Micropaleontology, 37(3):116 
Motiei, H, 1993, Stratigraphy of Zagros in Treatise of geology of Iran, Iran Geological Survey, 1:281-289, In Farsi

Premoli Silva, I. and Sliter, W. V. 1995. Cretaceous planktonic foraminiferal biostratigraphy and evolutionary trends from the Bottaccione section, Gubbio, Italy. Paleontographia Italica $82,89 \mathrm{pp}$.

Premoli Silva, I. and Verga, D. 2004. Practical Manual of Cretaceous Planktonic Foraminifera. In: Verga, D. and Rettori, R., (Eds.): International school on Planktonic Foraminifera.., Universities of Perugia and Milano, Tipografia Pontefelcino, Perugia283 pp

Sliter, W.V, 1989, Biostratigraphic zonation for Cretaceous planktonic foraminifers examined in thin section, Journal of Foraminiferal Research, 19(1): 1-19

Setudehnia, A, A, 1972, Lexique Stratigraphique International ASIE v.III, Fascicule, b.2-Iran du sud Quest

Robaszynski, F., Caron, M., 1979. Atlas de foraminife'rs planctoniques du Cre'tace' moyen (Mer Boreale et Tethys), premie're partie. Cahiers de Micropaleontologie 1 (1-185 pp.).

Robaszynski, F., and Caron,M , 1995. Foraminifers planktonique du cretace: Bulletine Society Geological of France , t.166, p.681-698

Vaziri Moghaddam, H , 2002 , Biostratigraphic study of the Ilam and Gurpi Formations based on planktonic foraminifera in SE of Shiraz, Iran, published in Journal of Science, Islamic Republic of Iran, 13:339-356

Wynd, J.G, 1965, Biofacies of the Iranian Oil Consortium Agreement Area IOOC, Rep.No.1082, Unpublished 